\title{
PERFORMANCE OF SOYBEAN VARIETIES IN HILLY AREAS
}

\author{
M. Shaheenuzzamn, A. Biswas, M. M. Karim and M. K. Islam \\ Agronomy Division, Bangladesh Agricultural Research Institute, Joydebpur, Gazipur \\ Corresponding author: shaheenuzzamn@gmail.com
}

Key words: Hill agriculture, protein and vegetable oil, soybean

Soybean (Glycine max L. Merr.) is a leguminous crop and a good source of protein and vegetable oil. It can play a vital role in balancing the protein deficiency of our diet (Mondal and Wahhab, 2001; Rahman, 2003). At present, the domestic oilseed production of Bangladesh is 0.63 million tons, which gives only 0.20 million tons of edible oil and can meet 25-30\% requirement (Hossain and Rahman, 2008). To fulfill the requirement, Bangladesh is to import 1.20 million tons of edible oil annually at a cost of nearly Tk. 40 billions. There is a possibility of producing 1.6-1.8 million tons of soybeans from 0.7 million hectares of char land and from other seasonal fellow land in Bangladesh as well hill region in Chittagong Hill Tract. So, the present experiment has been undertaken to evaluate the performance of soybean varieties in respect of maturity period, seed yield and yield contributing characters at three different locations of CHT zone for the development of soil condition as well as increase productivity of oil crops.

The experiment was conducted at hill valley of Hill Agricultural Research Station, Ramgarh, Khagrachari during kharif-2 season of 2011-12 and 2012-13. The soil of this hill area belongs to AEZ 27 and the soil bears acidic soil. Three different soybean varieties (Shohag, BARI Soybean-5 and BARI Soybean-6) were included in the experiment. The trial was laid out in a randomized complete block design with five replications. The unit plot size was $3 \mathrm{~m}$ x $3 \mathrm{~m}$. Seeds of soybean (Shohag, BARI Soybean-5 and BARI Soybean-6) were sowing according to treatment with the spacing of $30 \mathrm{~cm} \times 30 \mathrm{~cm}$. Lime was applied due to minimize the acidity effect. Fertilizers at the rate of $60-175-120-115 \mathrm{~kg} \mathrm{ha}^{-1}$ as urea, triple super phosphate (TSP) muriate of potash (MoP) and Gypsum respectively along with 10 ton cowdung. All fertilizers were applied as basal during final land preparation. Weeding, irrigation and insecticides were sprayed as and when required to maintain an optimum growth condition for the crop. It was harvested after 95 Days after sowing when the pods were turned to yellowish color and leaves were fallen down. Plant height, number of branches plant ${ }^{-1}$, number of pods plant ${ }^{-1}$, number of seeds plant ${ }^{-1}$, weight of seeds plant $^{-1}, 1000$-seed weight and yield $\left(\mathrm{t} \mathrm{ha}^{-1}\right)$ were recorded. The collected data were analyzed statistically and means were separated using LSD test at $5 \%$ level of significance.

The result showed that there were significant differences observed among the tested Soybean varieties, i.e., Plant height $(\mathrm{cm})$, No. of branch plant ${ }^{-1}$, No. of pod plant ${ }^{-1}$, no. of seed pod ${ }^{-1}$, weight of seeds plant ${ }^{-1}$ (g), 1000-seed wt. (g) and yield $\left(\right.$ tha $^{-1}$ ). The soybean var. BARI Soyabean-6 was recorded the highest plant height 60.00 and $61.50 \mathrm{~cm}$ among the varieties and the lowest 57.35 and $55.76 \mathrm{~cm}$ by Shohag in 2011-12 and 2-12-13, respectively. The highest number of pods plant $^{-1}$ (14.00 and 13.66) was found in BARI Soybean-6 in both the years. The highest numbers of seeds $\operatorname{pod}^{-1}$ (2.68 and 2.48) were recorded from the variety Shohag while BARI Soyabean-5 recorded the lowest number of seeds pod $^{-1}(2.47)$ during 2011-12 and BARI Soyabean-6 (2.16) during 2012-13. The highest weight of seeds plant ${ }^{-1}$ (8.77 $\mathrm{g}$ and $7.92 \mathrm{~g}$ ) was recorded in Shohag in both years and the lowest weight of seeds plant ${ }^{-1}$ (6.45 $\mathrm{g}$ and $5.58 \mathrm{~g}$ ) were from BARI Soybean-6. The highest 1000-seed weight (90.00 g and $89.00 \mathrm{~g})$ were recorded from BARI Soybean-5 and the lowest 1000-seed weight from BARI Soyabean-6. The highest seed yield of 0.58 and $0.55 \mathrm{t} \mathrm{ha}^{-1}$ was recorded from BARI Soybean-6 that followed by Shohag $\left(0.52\right.$ and $\left.0.50 \mathrm{t} \mathrm{ha}^{-1}\right)$ and the lowest yield $\left(0.48 \mathrm{t} \mathrm{ha}^{-1}\right.$ and $\left.0.46 \mathrm{t} \mathrm{ha}^{-1}\right)$ from BARI Soybean-5 for both the cropping years. Although average yield of BARI released varieties is $1.5-2 \mathrm{t} \mathrm{ha}^{-1}$ but in the hilly region, all the varieties were produced lower yield. It might be due to prevailing lower temperature during growing season. 
Shaheenuzzamn et al.

Beside this, lack of irrigation of water facilities in CHT region which caused drought condition might be another limitation.

Table 1. Different characters of soybean varieties in hilly region of Ramgarh, Khagrachari, 2011-12 and 2012-13

\begin{tabular}{l|c|c|c|c|c|c|c|c}
\hline Varieties & \multicolumn{2}{|c|}{$\begin{array}{c}\text { Plant height } \\
(\mathrm{cm})\end{array}$} & \multicolumn{2}{c|}{$\begin{array}{c}\text { No. of branches } \\
\text { plant }^{-1}\end{array}$} & \multicolumn{2}{c|}{ No. of pods plant $^{-1}$} & \multicolumn{2}{c}{ No. of seeds pod $^{-1}$} \\
& $\begin{array}{c}2011- \\
12\end{array}$ & $\begin{array}{c}2012- \\
13\end{array}$ & $2011-12$ & $2012-13$ & $2011-12$ & $2012-13$ & $2011-12$ & $2012-13$ \\
& 57.35 & 55.76 & 2.00 & & & & & \\
\hline Shohag & 58.66 & 59.42 & 1.95 & 2.16 & 13.50 & 12.94 & 2.58 & 2.48 \\
$\quad$ BARI & & & & & & 13.42 & 2.47 & 2.36 \\
Soybean-5 & & & & & & & \\
BARI & 60.00 & 61.50 & 2.43 & 2.28 & 14.00 & 13.66 & 2.56 & 2.16 \\
Soybean-6 & & & & & & & & \\
\hline LSD $_{(0.05)}$ & 3.5 & 3.76 & 6.75 & 0.49 & 3.07 & 2.08 & 0.7 & 0.16 \\
CV (\%) & 4.7 & 5.3 & 10.9 & 15.9 & 9.0 & 10.8 & 7.8 & 6.8 \\
\hline
\end{tabular}

Table 2. Yield and yield contributing characters of soybean varieties in hilly region of Ramgarh, Khagrachari, 2011-12 and 2012-13

\begin{tabular}{l|cc|c|c|c|c}
\hline \multirow{2}{*}{ Varieties } & \multicolumn{2}{|c|}{ Wt. of seeds plant } & \multicolumn{2}{c|}{$\begin{array}{c}\text { 1000-seed wt } \\
\text { (g) }\end{array}$} & \multicolumn{2}{c}{ Seed yield } \\
& \multicolumn{2}{|c|}{$\left.\mathrm{(tha}^{-1}\right)$} \\
\cline { 2 - 7 } & $2011-12$ & $2012-13$ & $2011-12$ & $2012-13$ & $2011-12$ & $2012-13$ \\
\hline Shohag & 8.77 & 7.92 & 89.90 & 88.60 & 0.52 & 0.50 \\
BARI Soybean-5 & 7.50 & 7.24 & 90.00 & 89.00 & 0.48 & 0.46 \\
BARI Soybean-6 & 6.45 & 5.58 & 87.35 & 88.40 & 0.58 & 0.55 \\
\hline LSD $_{(0.05)}$ & 2.10 & 1.10 & 4.9 & 5.78 & 0.28 & 0.14 \\
CV (\%) & 3.5 & 5.4 & 7.8 & 8.2 & 25.09 & 30.6 \\
\hline
\end{tabular}

Results of the present study indicated that soybean BARI Soybean- 6 would be suitable for cultivation in hill region but more trial is needed the variety in the hilly region.

\section{References}

Hossain, M. D. and M. A. Rahman. 2008. Toil beez fasal utpadan briddhir somosya o tar somadhaner loskhe BARI udbhabita projukti somuha. In: Krishi Projukti Manual, M. Nazim Uddin, M. Ahmed, M. S. Alam, R. U. Shamim, S. Ullah and K. M. Salahuddin (eds), Bangladesh Agril. Res. Inst., Joydebpur, Gazipur. pp.39-43.

Mondal, M. R. I. and M. A. Wahhab. 2001. Production Technology of Crops. Oil seed Research Center, Bangladesh Agril. Res. Inst., Joydebpur, Gazipur. pp.1-10.

Rahman, L. 2003. Studies on the development of varieties, production technology, food and fish feed uses of soybean in Bangladesh (BAU-USDA Soybean Project BG-ARS 107).p.6. 